\title{
Gambaran pengetahuan siswa SMAN 8 Malang tentang foodborne disease
}

\author{
Ajeng Erika Prihastuti Haskito*, Citra Sari, Fidi Nur Aini Eka Puji Dameanti
}

Fakultas Kedokteran Hewan, Universitas Brawijaya, Malang, Jawa Timur

\begin{abstract}
ABSTRAK: Foodborne disease adalah penyakit yang terjadi akibat mengkonsumsi makanan dan minuman yang terkontaminasi oleh agen mikroorganisme atau zat toksin. Kejadian foodborne disease, seperti sakit perut dengan gejala klinis diare dan thypoid pada siswa di sekolah masih cukup tinggi hingga saat ini. Hal ini disebabkan kurangnya pengetahuan tentang foodborne disease serta kurangnya penerapan perilaku hidup bersih dan sehat. Penelitian gambaran pengetahuan tentang foodborne disease ini bersifat deskriptif, dengan design penelitian menggunakan cross sectional study dengan populasi adalah siswa SMAN 8 Malang. Sampel dipilih secara purposive sampling yang memenuhi kriteria inklusi, sehingga diperoleh sampel 35 siswa kelas X-a SMAN 8 Malang. Hasil penelitian diperoleh informasi sebesar 34.29\% pernah mengalami sakit akibat jajanan di sekolah. Hasil analisa menunjukkan hanya $28.57 \%$ siswa mengetahui tentang foodborne disease, $22.86 \%$ mengetahui ciri-ciri jajanan terkontaminasi bakteri, dan $14.29 \%$ mengetahui penyakit foodborne disease akibat bakteri. Persentase siswa belum terbiasa menerapkan perilaku cuci tangan sebelum makan sebesar $80 \%$. Gambaran pengetahuan dan perilaku hidup bersih dan sehat di sekolah siswa SMAN 8 Malang tentang foodborne disease masih sangat kurang.

Kata kunci:

foodborne disease, pengetahuan, siswa sekolah
\end{abstract}

\section{- PENDAHULUAN}

Siswa sekolah merupakan kelompok manusia yang rentan terhadap bakteri dan virus yang disebarkan melalui makanan (Sholikhah \& Sustini 2013). Foodborne disease adalah istilah untuk penyakit yang disebabkan atau ditularkan melalui makanan yang terkontaminasi oleh agen patogen penyebab penyakit (Naully \& Mathilda 2018). Penyebab utama siswa sekolah terkena foodborne disease adalah perilaku yang kurang menjaga kebersihan dan kesehatan, sehingga agen penyebab mudah masuk melalui makanan (Herman et al. 2015). Studi yang dilakukan oleh WHO terdapat 31 agen patogen, termasuk bakteri, virus, parasit, toksin, dan kimia penyebab 600.000.000 kesakitan dan 420.000 kematian. Contoh patogen dari kelompok bakteri yang paling banyak di Indonesia seperti Escherichia coli (15-20\%), Salmonella sp. (1-5\%), Campylobacter jejuni (15-20\%), Shigella sp. (5-15\%), Vibrio cholera (5$10 \%)$, Staphylococcus aureus, Listeria monocytogenes, Clostridium botulinum (Naully \& Mathilda 2018; Asharina \& Nadiya 2016). Penelitian ini bertujuan agar siswa mengetahui contoh-contoh penyakit foodborne disease beserta bahayanya, sehingga dapat mencegah diri siswa dari foodborne disease melalui cara konsumsi jajanan di sekolah dengan menerapkan perilaku hidup bersih dan sehat.

\section{- BAHAN DAN METODE}

Penelitian ini dilakukan bersama kegiatan pengabdian kepada masyarakat untuk mengedukasi siswa sekolah yang dilaksanakan di SMAN 8 Malang. Penelitian deskriptif, dengan desain cross sectional study. Populasi adalah siswa SMAN 8 Malang yang dipilih secara purposive sampling dengan kriteria inklusi: (1) umur 15-16 tahun; (2) kelas tidak ujian; (3) kondisi sehat; dan (4) jumlah siswa satu kelas $>30$ orang. Kegiatan edukasi dilaksanakan melalui ceramah tentang foodborne disease beserta beberapa contoh kasus penyakitnya yang disebabkan oleh bakteri. Kegiatan ceramah didukung dengan pameran poster dan permainan terkait materi yang telah disampaikan. Instrumen pengumpul data, meliputi pre-test, post-test, serta wawancara untuk mengisi kuesioner, data ditabulasi dalam Microsoft Excell dan dianalisis secara deskriptif.

\section{- HASIL DAN PEMBAHASAN}

SMAN 8 Malang berada di Jln Veteran No. 37, Sumbersari, Kecamatan Lowokwaru, Kota Malang. Hasil pengamatan menunjukkan banyak penjual jajanan di depan sekolah. Kegiatan edukasi dilakukan sebagai tindakan preventif foodborne disease pada siswa karena usia tersebut berada pada tahap perkembangan konkret operasional, sehingga peka menerima perubahan dan pembaharuan (Nurbiyati \& Wibowo 2014). Siswa kelas X-a SMAN 8 Malang sebanyak 35 orang (laki-laki 17\%, perempuan 83\%) mengikuti

Diterima: 09-01-2019 | Direvisi: 26-02-2019 | Disetujui: 28-02-2019

(C) 2019 CC-BY-SA. Ini adalah artikel Open Access yang didistribusikan berdasarkan ketentuan dari Creative Commons Attribution Share Alike 4.0 International License (https://creativecommons.org/licenses/by-sa/4.0/). 
kegiatan ini. Permasalahan utama siswa terkait bahaya foodborne disease adalah keterbatasan pengetahuan tentang foodborne disease beserta contoh-contoh penyakit, ciri-ciri jajanan di sekolah yang terkontaminasi bakteri, dampaknya, dan kebiasaan menerapkan cuci tangan sebelum makan.

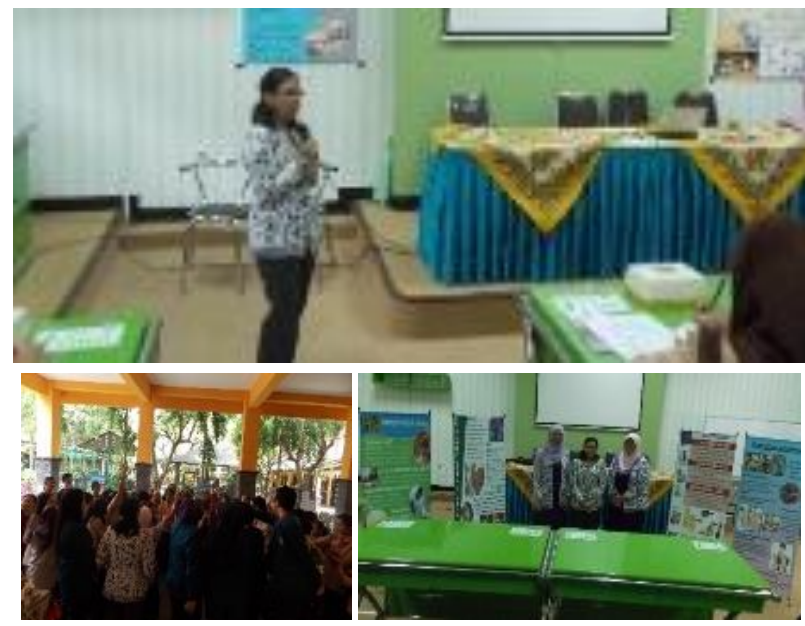

Gambar 1 Ceramah, permainan, dan poster tentang foodborne disease

Tabel 1 Gambaran pengetahuan foodborne disease pada Siswa SMAN 8 Malang

\begin{tabular}{|c|c|}
\hline Variabel & Total $(\%)$ \\
\hline Pernah sakit akibat jajanan di sekolah & $\begin{array}{l}12(34.29) \\
23(65.71)\end{array}$ \\
\hline Mengetahui tentang foodborne disease & $\begin{array}{l}10(28.57) \\
25\end{array}$ \\
\hline $\begin{array}{l}\text { Mengetahui tentang ciri-ciri jajanan di sekolah } \\
\text { yang terkontaminasi bakteri } \\
\\
\text { Ya } \\
\text { Tidak }\end{array}$ & $\begin{array}{ll}8 & (22.86) \\
27 & (77.14)\end{array}$ \\
\hline $\begin{array}{lr}\text { Mengetahui nama-nama penyakit } & \text { foodborne } \\
\text { disease yang disebabkan bakteri } & \text { Ya } \\
& \text { Tidak }\end{array}$ & $\begin{array}{ll}5 & (14.29) \\
30 & (85.71)\end{array}$ \\
\hline $\begin{array}{l}\text { Menerapkan perilaku hidup bersih dan sehat di } \\
\text { sekolah (klausa: mencuci tangan sebelum makan) } \\
\text { Ya } \\
\text { Tidak }\end{array}$ & $\begin{array}{lr}7 & (20.00) \\
28 & (80.00)\end{array}$ \\
\hline
\end{tabular}

Hasil analisa menunjukkan pengetahuan foodborne disease hanya sebesar $28.57 \%$ dari total siswa. Siswa tersebut mengetahui foodborne disease kemungkinan karena pernah mengalami sakit akibat foodborne disease atau mendapatkan informasi dari keluarganya. Hal ini selaras dengan pengetahuan nama-nama penyakit foodborne disease yang disebabkan bakteri sebesar $14.29 \%$.

Hasil pengawasan jajanan di sekolah oleh 18 BPOM di 19 provinsi di Indonesia, menunjukkan $39.96 \%$ jajanan di sekolah tidak layak dikonsumsi karena positif Salmonella sp. dan Escherichia coli (Naully \& Mathilda 2018). Arisanti et al. (2017) melaporkan pada tahun 2000-2015 jumlah kasus keracunan jajanan di sekolah sebesar $13.7 \%$. Kasus tersebut masih ada hingga saat ini dimana sebanyak $34.29 \%$ dari 35 siswa X-a SMAN 8 Malang pernah sakit akibat jajanan di sekolah.
Terdapat kenaikan dari data pre-test (rata-rata nilai 34) dan post-test (rata-rata nilai 81 ). Peningkatan pengetahuan siswa X-a SMAN 8 Malang tentang foodborne disease dan penerapan hidup bersih dan sehat berupa mencuci tangan sebelum makan, diharapkan siswa menjadi konsumen yang pintar dan selektif dalam memilih dan mengkonsumsi jajanan di sekolah. Kegiatan ini perlu dilakukan berkelanjutan pada target sasaran edukasi yang lain. Kegiatan edukasi ini dapat menjadi pemicu sekolah-sekolah lain untuk mengedukasi para siswanya.

\section{- SIMPULAN}

Sebagian besar siswa sekolah belum mengetahui mengenai foodborne disease dengan beberapa macam contoh penyakit yang termasuk kedalamnya, sehingga pola jajan di sekolah masih sembarangan serta perilaku hidup bersih dan sehat di sekolah belum menjadi suatu kebiasaan. Ceramah yang dilakukan, poster yang dipamerkan, dan permainan yang dilakukan mampu meningkatkan gambaran pengetahuan siswa SMAN 8 Malang tentang foodborne disease.

\section{- INFORMASI PENULIS}

Penulis untuk Korespondensi

*AEP: drherika1989@gmail.com

Laboratorium Kesmavet, Fakultas Kedokteran Hewan, Universitas Brawijaya, Malang

\section{- TERIMA KASIH}

Fakultas Kedokteran Hewan Universitas Brawijaya atas dana penelitan dan pengabdian kepada masyarakat DPP-SPP dan SMAN 8 Malang sebagai pendukung fasilitas pelaksanaan penelitian ini.

\section{- PUSTAKA ACUAN}

Arisanti RR, Indriani C, Wilopo SA. 2017. Kontribusi agen dan faktor penyebab kejadian luar biasa keracunan pangan di indonesia: kajian sistematis. BKM Journal of Community Medicine and Public Health. 34(3):99-106.

Asharina I, Nadiya AN. 2016. Beberapa mikroba patogenik penyebab foodborne disease dan upaya untuk menurunkan prevalensi foodborne disease di indonesia: mikroba dalam foodborne diasease dan pencegahanya. Fermenstation Institut Teknologi Bandung. 1-7.

Herman, Napirah MR, Sherlina. 2015. Faktor-faktor perilaku hidup bersih dan sehat yang berhubungan dengan kejadian foodborne disease pada anak di sekolah dasar negeri (SDN) inpres 3 tondo kota palu. Jurnal Kesehatan Tadulako. 1(2):1-14.

Naully PG, Mathilda F. 2018. Pencegahan penyakit akibat jajanan sekolah dengan edukasi kesehatan dan undang-undang perlindungan konsumen. Gemassika: Jurnal Pengabdian Kepada Masyarakat. 2(2):80-90.

Nurbiyati T, Wibowo AH. 2014. Pentingnya memilih jajanan sehat demi kesehatan anak. Jurnal Inovasi dan Kewirausahaan. 3(3): 192-196.

Sholikhah HH, Sustini F. 2013. Gambaran perilaku hidup bersih dan sehat tentang foodborne disease pada anak sekolah di SDN babat jerawat I kecamatan pakal kota surabaya. Buletin Penelitian Sistem Kesehatan. 16(4):351-362. 